morbific agent may be required to exhibit spread or duration of vitality may not be favourable, a small fact well worth remembering in fighting plague. I'he sanitarian may, with confidence, apply the principle that every chance of success is of solid advantage to him, and nay remember that fayouring accidents or chances affecting the disposal of infectious matter need not always be with the enemy.

When plague made itself felt in Hong-Kong in 1894 I issued a circular to port medical officers warning them of its possible entrance to this presidency. The moment it was ascertained that plague had entered Bombay, instead of adopting a system of quarantine and observation in camps $I$ at once advised local bodies to employ passport surveillance of the type contemplated by the Local Government Board in England with reference to cholera. This was subsequently legalised by the Madras Government using the Epidemic Diseases Act; so that, by taking advantage of the revenue system of village organisation, every village and town in the area of 141,726 square miles of this presidency became a centre of sanitary action and surveillance. All persons proceeding from towns or villages "notified" as infected are required to take passports binding them to undergo surveillance during ten days in whatever localities they halt at. The first actual advent of plague in the city of Madras was in October, 1897, and although, as a matter of fact, in this first experience there was neg]ect of one day in surveillance which nearly led to a clisaster, the tracing of cases was clue to the existence of the passport system in its yet incomplete and non-legalised form. Since then, in the city of Madras 67 cases of imported plague have occurred, of which 59 have been directly, and the rest indirectly, detected under this system. Last year 79,488 passports were registered and only 2 per cent. of the holders were not traced. The trouble involved up to date to the municipal staff must have been great, but so far as one could perceive the result has been of enormous benefit to the 500,000 inhabitants of the city of Madras. Necessarily, the system is far from infallible. Irrespective of the possible arrival of infected material there must at times be evasions in the case of persons from infected areas who may or may not be incubating plague, the chances always, however, being heavily in favour of their not being infected, as shown by the large average number of cases that pass through the period of surveillance before a single case of plague is detected ${ }^{1}$ namely, 5000. Indeed, that the passport system has materially diminished without removing absolutely the chances of infection of the city is shown by the fact that in April this year Madras went through a small outbreak of indigenous plague, in all probability as a result of an evasion of the passport rules. The actual origin of infection was never ascertained, although the most reasonable hypothesis was the native rumour that the first death was in the case of a person who had been in the infected area of Bangalore and had evaded the passport rules on arrival. The suspicious death was fortunately reported by an anonymous petition to the medical officer of health who was able to warn in time the district medical officer in charge of a suburb beyond municipal limits to which certain of the contacts adjourned. The result was that the contacts were traced and on all the usual measures being applied to the infected localities the disease was stamped out, but not until 11 cases had occurred in the suburbs and five in the city of Madras. Luckily rats did not get infected. Not one of the cases was of the bubonic variety they were toxic, pneumonic, and intestinal-showing, I think, that the Madras environment is capable of nurturing a very virulent strain of plague. 'The diagnosis of the last pneumonic case-a contact of a previous pneumonic case-was bacteriologically confirmed by Lieutenant-Colonel Bannerman, I.M.S., the then superintendent of the King Institute, Madras. As, then, you have remarked, there is nothing in the sanitary condition of Madras per se that has hitherto effected its protection. The chief factor in bringing about that result has been the activity of the municipal staff in keeping persons from infected areas under surveillance, aided by the passport system.

As a result of this method of fighting plague from the commencement of danger of importation numerous imported cases in hitherto uninfected areas hav : been detected in all parts of the presidency. Following prompt action by local ofticers

1 In an indigenonsty infecterl ris rict the examination of cach 1600 jassport holders arriving in uninfecter areas secured one case of plague.-W. G. K. in these cases no spread has taken place. Errors of judgment or breakclown of methods have led to indigenou. plague in certain districts. But it las spreal very slowly, and instead of there being widely scattered areas infected throughout the presidency ultimately fatcr to coalesce consequent upon the yielding of the intermediate areas, the cnrious result has been seen of plague being confined to the districts bordering upon the great centrenamely, the Mysore Territory, whence the infection is constantly imported and where the repetition of chances is consequently greatest. Year after year a gradual addition to the numbers of these districts has occurred and an advance towards the central and sonthern districts is at the present time threatened. It can scarcely be hoped that Madras city will escape being indigenously infected, but in the meantime the struggle by Government and local authorities in this presidency has been well sustained ancl the result has been, I think, to earn a grade of protection of life and trade that would not have been feasible had plaguc been "let rip." I am, Sirs, yours faithfully,

\author{
W. G. KnNG,
}

Marlras, July 13th, 1904

Lieutenant-Colonel I.M.S.

\section{LAYMEN AND ELECTRICAL TREATMENT.}

To the Editors of THE LANCET.

SInS, - In answer to Dr. E. Stanley Smith's letter in THE LANCE'l of August 6th, p. 4233, T should like to bring before lim the following considerations. First, the expense. I am sure that any medical man working at electro-therapentics would willingly treat cases at whatever fee their medical adviser thought or knew ther could afford. In suitable cases properly vouched for by their practitioner no fee for treatment in private would, I am sure, he charged. From what I know of the charges of my registered confrires I am of opinion that they would agree with me that, as a rule, skiagrams from £3 to $£ 10$ are the peculiar perquisite of the unregistered quack. I shall be pleased to send to anv registered medical practitioner the list of the British Electro-Therapentic Society, upwards of 200 medical men in London and the provinces, who would I am certain charge the fee that the medical attendant thought proper. Regarding the "absurclity of contending that there can be anything harmful to a patient in getting a larman to take a skiagraph," I would contend, Sirs, that it most assuredly depends on what the merlical man vants. Does he want a picture? or Does he want to have skilled medical advice on the interpretation of the skiagraph:- -things which, as you are well aware, are totally different in nature.

Again, we should be pleased to hear of the "layman." electro-therapentic institute, \&c., who, possessing a certain amount of elementary knowledge of anatomy, is still capable of knowing when to stop in treating any case with $x$ rays, high-frequeney, or any other form of electrical treatment. If this does not require a full medical training how is it that our hospital statistics are better than those of laymen or lay institutes? Why is it that the history of our hospital and, alas, often our private patients is very generally that they have tried this or that quack or quack institute and paid good fees before they come to us or our out-patient department for cure? This can be easily proved by a visit to any hospital with the requisite electrical department.

Secondly, regarding Dr. Smith's statement that "medical men shrink from sending their patients to another medical man owing to their diagnosis and treatment being overhauled by another," I would only ask the following question: Will the diagnosis and past treatment, good or bad, be upheld by a quack or quack institute rather than by one's own registered colleague?

Mr. H. Valentine Kinaggs's letter in the same issue contains a somewhat alluring but dangerous suggestion. It is that medical practitioners who practise electro-therapeutics should advertise to obtain the support of some nedical men and also to act as a foil to the numerous electrical quacks. This would entail de-registration. Does Mr. Krnaggs seriously consider what this means to a duly registered medical practitioner? Would he give the same advice to the dermatologist, surgeon aurist, surgeon oculist, and laryngologist, or any other of our special practitioners! I venture to think, sirs, that should we attempt to follow Mr. Knaggs's advice he would probably be the first to cast at us a stone. 
Electro-therapentics is recognised as a special branch of our art at all our large hospitals and most of the smaller ones and to all those who have carcfully watched its development it comes somewhat as a surprise that any well-informed medical practitioner should for one moment be-little the assistance and help to medicine and surgery which the intelligent medical study of electro-therapeutics has already conferred.

1 am, Sirs, yours faithfully,

Berlfort-square, W.C., August 8th, 1904. CHISHorm WuLLIAMS.

To the Editors of THE LANCET.

SIRs,-It is indeed sad to see how some members of the profession who love to pose as veritable models of light and leading in ethical matters, disregarding the General Medical Council's notice re "covering," still persist in countenancing unqualified practice by sending their patients to laymen for electrical treatment. The reasons suggested by Dr. $\mathrm{F}$. Stanley Smith in 'THE IsNCE' of August 6th, p. 423, are at the best but poor and specious excuses for such irregularities. They are: expense, squeamishness about having their cliagnosis and ideas of treatment overhauled and lastly, the elementary knowledge of anatomy required for the actual application of electricity.

A medical man who would rashly venture, on the score of expense, to send his patient to a "skilled" bone-setter, "who has an elementary knowledge of anatomy," would, I fear, have a hard time of it in struggling to convince operative surgeons of his singular regard for altruistic principles. So likewise ro ophthalmic surgeons consider as something other than "alsurd to contend that there can be anything harmful to a patient in gotting a skilled layman to" examine " him for diagnostic purposes." A correct diagnosis is the only sure basis of rational treatment A patient who can afford to pay a fee of 30 to 100 guineas for a single operation can well spare an additional two or three guineas for an expert's opinion that will clinch the diagnosis in a doubtful case. Again, a skiagram is no more a measure of the exact value of a medical radiographer's services than a bottle of physic is of that of the veneral practitioner who dispenses. It is true that a certain section

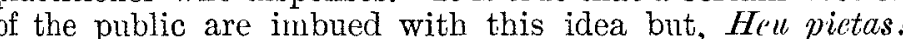
similar views are not held in professional circles. By those best fitted to express an opinion radioscopy rather than radiography is regarded as the surest guide to a correct diagnosis, although the latter has its uses for purposes of localisation and as confirmatory cvidence in a court of law. It may easily be inferred from what has been already said that a skiagram is only a record of one phase of an examination with the Roentgen rays. It requires a vast amount of training to correctly interpret skiagraphic records in a search for calculi, effusions, tumour formations, \&c.; even more experience is needed to tell which surface of the body or part was in immediate relation with the plate. This being the case, surely a labourer is worthy of his hire.

A great and wise physician has said, "We can learn a lot by our very mistakes, and none but a conceited ass would allow vanity to stand in the way of knowledge." 'Thank goodness, the profession at large are not to any extent afllicted with this troublous complaint, which spells death to consultations between medical men, whether specialists or general practitioners. How much reliance can be placed on "the "skilled" layman "nko has an elementary knonledge of anatomy"? Is he likely to prove the superior of the average medical student in this respect? It cannot be too strongly emphasised that something more than a thorough acquaintance with the working of electrical apparatus and an elementary knowledge of anatomy is essential to success in electrotherapy. Experience that combines medical knowledge with that of the physiological and pathological effects of treatment and mastery of electrical instrumentation alone can guide us in making a juclicious selection of cases and in planning out the exact combination that will prove most efficacions. The ordinary knowledge of disease of the practitioner who sends his cases to the skilled layman, who has a sound knowledge only of the workings of his apparatus, cannot supply this deficiency. Experience, which is a staff to the hand of the wise, is a rod for the back of fools. Unfortunately, in this case the punishment is too often administered by proxy, as it is the patient who suffers both in bealth and pocket for the selfish considerations which prompt his medical attendant to suggest this unethical course.

I am, Sirs, yours faithfully,

Levtonstone, Aug. 9th, 1904.

CLARENCE A. WRIGH'T

\section{FREE OPERATIONS.}

To the Editors of THE LANCET.

Srrs,--Your excellent special article on "Medicine and the Law" in THE LANCE' of August 6th, p. 419, reminds us that in the case in question Miss Thorne operated without fee or reward, and has now been recompensed by the anxiety of a trial and the unpleasantness of a verdict against her. Was this patient really a case deserving: of free operation? Would she not have been able to pay a moderate fee either to a London operator or to one of the excellent surgeons in the town from which she came? I am sure most provincial surgeons could give instances of well-to-do patients who have got operations done free in metropolitan hospitals or nursing homes and whose object in leaving their own localities was to escape the payment of surgical fees. Can any argument be advanced to justify this state of things? Probably it is due to the overcrowded state of the special departments of the profession in metropolitan cities and the desire of junior practitioners to gain experience, but that does not make it right. In some cases it is an abuse of hospital funds subscribed to benefit the deserving poor. In all cases it is an abuse of the charity of the medical profession and an injustice to provincial surgeons. Surely every possible care should be taken to separate the undeserving and often ungrateful from the really poor.

I am, Sirs, yours faithfully,

Belfast, August 8th, 1904. JOHN CAMPBELL.

\section{THE INSURANCE OF MEDICAL MEN AGAINST THE DANGERS OF THEIR PROFESSION.}

To the Editors of THE LANCET.

SIRs,-The first part of the letter which appeared in THE LANCET of July 30th, p. 327, signed by Mr. John MacGregor contains a mis-statement of fact that calls for immediate contradiction. The subject of misrepresentation when raised by my counsel was at once objected to by the counsel representing the Scottish Accident Company and the objection was upheld by the arbitrator who said that it was not material to the matter under arbitation, which he further explained was limited to the terms of the policy which constituted the contract between the parties to the suit. I was therefore precluded from calling evidence on this point, although the agent, Mr. Oroucher, was present in court. The bias underlying the entire letter is so selfevident as to relieve me of the necessity of dealing with any other of the points raised.

I am, Sirs, yours faithfully,

Guy's Hospital, S.F., August 5th, 1904. JNo. EYRE.

\section{THE REPUTATION OF SIR EVERARD HOME.}

To the Editors of THE LANCET.

SiRs, - The reputation of Sir Everard Home is severely dealt with in an annotation in THE LANCET of July 23rd, p. 234. Everyone must admit that he put himself hopelessly in the wrong by burning the bulk of the MSS. of John Hunter 30 years after the latter's death. The circumstance that he did this just after publishing a large work of his own and after his co-executor, Dr. Matthew Baillie, had left London gives to the act a worse complexion. But strict justice must be claimed for every offender, and I ask, Is it fair to write, apropos of John Hunter's MSS., that "the windbag Home owed all his knowledge and reputation to them and became F.R.S. and Hunterian lecturer on the strength of them" ? Home was Hunter's brother-in-law, his pupil from 1772, his senior executor, and he wrote an excellent and appreciative life of Hunter the year after his death in 1793 . The best account of Home that I know is that given by Sir Benjamin Brodie in his autobiography, a little work which is a pattern of candour and right feeling. Brodie was a pupil of Home (1803) and later his assistant, continuing for a number of years to work with him in dissections, in comparative anatomy, \&c. He therefore knew him intimately, and yet being himself connected with Matthew Baillie through the Denmans, and constantly working with Clift, Brodie was also in touch with other custodians of John Hunter's fame, 'The dispassionate 